\title{
ВИКОРИСТАННЯ МОДЕЛЮВАННЯ У КОНТЕКСТІ УДОСКОНАЛЕННЯ ІНВЕСТИЦІЙНОГО ЗАБЕЗПЕЧЕННЯ СІЛЬСЬКОГОСПОДАРСЬКИХ ПІДПРИЕМСТВ НА ТЕРИТОРІЯХ РАДІАЦІЙНОГО ЗАБРУДНЕННЯ
}

\author{
MODELING USE IN THE CONTEXT \\ OF IMPROVING INVESTMENT SUPPORT \\ OF AGRICULTURAL ENTERPRISES \\ IN RADIOACTIVELY CONTAMINATED AREAS
}

\author{
Каленська Віталіна Петрівна \\ старший лаборант, \\ Житомирський державний університет імені Івана Франка \\ ORCID: https://orcid.org/0000-0002-8174-9026 \\ Kalenska Vitalina \\ Zhytomyr Ivan Franko State University
}

\begin{abstract}
Наукова стаття присвячена вирішенню проблематики інвестиційного забезпечення сільськогосподарських підприємств на територіях радіаційного забруднення України. У дослідженні доведена наявність значного дефріциту інвестиційних ресурсів у агровиробників з РЗТ країни, а також можливість вирішення проблеми за рахунок використання економіко-математичного моделювання. Обравши у якості результативної ознаки обсяг продукції сільськогосподарських підприємств на територіях радіаційного забруднення, а в якості фракторних ознак вартість фрінансового лізингу сільськогосподарських підприємств на територіях радіаційного забруднення, вартість кредитів, наданих кредитними спілками на сільськогосподарську діяльність, вартість кредитування сільськогосподарських підприємств депозитними корпораціями, крім НБУ, була доведена необхідність акцентувати увагу агровиробників з РЗТ на фрінансовому лізингу.

Ключові слова: економіко-математичне модулювання, інвестиційне забезпечення, радіаційно-забруднені території, сільськогосподарські підприємства, фінансовий лізинг.
\end{abstract}

Научная статья посвящена решению проблематики инвестиционного обеспечения сельскохозяйственных предприятий на территориях радиационного заражения Украины. В исследовании доказано наличие дефицита инвестиционных ресурсов у агропроизводителей с РЗТ страны, а также возможность решения проблемы за счет использования экономико-математического моделирования. Выбрав в качестве результативного признака объем продукции сельскохозяйственных предприятий на территориях радиационного загрязнения, а в качестве фракторных признаков стоимость фринансового лизинга сельскохозяйственных предприятий на территориях радиационного загрязнения, стоимость кредитов, предоставленных кредитными союзами на сельскохозяйственную деятельность, стоимость кредитования сельскохозяйственных предприятий депозитными корпорациями кроме НБУ, была доказана необходимость акцентировать внимание агропроизводителей с РЗТ на фринансовом лизинге.

Ключевые слова: экономико-математическое моделирование, инвестиционное обеспечение, радиационно-загрязненные территории, сельскохозяйственные предприятия, фринансовый лизинг.

The scientific article is dedicated to solving problems on investment support of agricultural enterprises in radioactively contaminated areas of Ukraine. The research has emphasized the connection between the problems on investment support of agricultural producers in the country and support of the stable growth of both the agrarian sector and the Ukrainian economy in general. The assessment of investment activity dynamics of agricultural enterprisers located in radioactively contaminated areas in the Zhytomyr region during 2002-2019 has detected the problems: on investment in fixed capital; the ratio of investment and earnings of the agricultural producers located in RCA in 2017-2019. The study has proved the existence of a significant shortage of investment resources among agricultural producers from radioactively contaminated areas as well as the possibility to solve the problem by using 
economic and mathematical modeling. By choosing agricultural production of producers located in radioactively contaminated areas as an effective feature and the value of financial leasing of agricultural enterprises located in radioactively contaminated areas, the cost of loans granted by credit unions for agricultural activities, the lending cost to agricultural enterprises by deposit-taking corporations, except NBU as factor features, the necessity to emphasize the financial leasing aspect for agricultural producers in radioactively contaminated areas has been proved. Economic and mathematical modeling has shown that the volume of products will increase by $5 \%$ in case of a $1 \%$ increase of the financial leasing value of agricultural enterprises in radioactively contaminated areas. The research has suggested the implementation of a comprehensive approach for introducing financial leasing to investment support of agricultural enterprises in radioactively contaminated areas. It will contribute to the following: accelerating their material and technical re-equipment; expanding access of small enterprises to financial resources; creation of a network of agricultural service cooperatives.

Keywords: economic and mathematical modeling, investment support, radioactively contaminated areas, agricultural enterprises, financial leasing.

Постановка проблеми. Сільське господарство $€$ провідною галуззю економіки України та одним з ключових драйверів розвитку національної економічної системи. Однак, потенціал економічного розвитку сільського господарства в країні реалізується не повністю через наявність значної кількості проблем, де головними є: низька ефективність законодавчого регулювання галуззі; відсутність есрективного ринку земельних ресурсів сільськогосподарського призначення; не ефективна система інститутів, у тому числі державних; фріскальний тиск; не ефрективна державна політика підтримки сільського господарства; розвиток ринку трудових ресурсів; десріцит інвестиційних ресурсів.

Серед проблем розвитку сільського господарства в Україні особливу увагу слід приділити проблемі десріциту інвестиційних ресурсів та недостатнього інвестиційного забезпечення агровиробників. Враховуючи значну потребу виробників сільськогосподарської продукції у інвестиціях на фроні необхідності збільшення фрінансових вкладень, як у основні, так і у оборотні активи, вважаємо, що саме удосконалення інвестиційного забезпечення $€$ ключовим фрактором забезпечення довгострокового сталого зростання сільського господарства в країні та окремих виробників агропродукції.

Особливо важливим є вирішення проблем інвестиційного забезпечення для сільськогосподарських підприємств з радіаційно-забруднених територій (РЗТ) України, оскільки здійснення ними операційної діяльності та забезпечення конкурентоспроможності вимагає залучення і використання значних обсягів фрінансових ресурсів. Актуальність вирішення проблематики інвестиційного забезпечення сільгосппідприємств з РЗТ зростає 3 врахуванням складностей залучення фрінансових ресурсів такими агровиробниками 3 інших джерел. У той же час, вирішення проблем інвестиційного забезпечення виробників сільськогосподарської продукції 3 радіаційнозабруднених територій повинно спиратись на використання можливостей економіко-математичного моделювання.

Аналіз останніх досліджень і публікацій. Питання залучення інвестицій та інвестиційного забезпечення сільськогосподарських підприємств в Україні досліджувались значною кількістю науковців, де можливо виділити напрацювання: О.О. Супрун [1], Б.В. Бусленко [2], М.І. Кисіль [3] та інших.

Проблематика інвестиційного забезпечення виробників сільськогосподарської продукції 3 радіаційно-забруднених територій розкривалась: А.С. Малиновським та Л.Д. Павловською [4], Л.В. Калиненко, Г.П. Перепелятниковим та Т.М. Івановою [5] і іншими науковцями.

В той же час, враховуючи значну актуальність проблем інвестиційного забезпечення сільськогосподарських підприємств з РЗТ України, відзначаємо необхідність активізації проведення наукових досліджень у цьому напрямку 3 акцентом на використання інструментів економіко-математичного моделювання.

Метою статті $€$ пошук шляхів удосконалення інвестиційного забезпечення сільськогосподарських підприємств на територіях радіаційного забруднення на основі використання економіко-математичного моделювання.

Виклад основного матеріалу дослідження. Сільськогосподарські підприємства 3 радіаційно-забруднених територій мають значні проблеми відносно інвестиційного забезпечення. Негативно на інвестиційну діяльність сільгоспвиробників з РЗТ впливає незначне фрінансування галузі, яке зумовлює значну спрацьованість устаткування, збільшення навантаження на одиницю застарілої техніки, що у свою чергу знижує ефективність фрункціонування сільськогосподарських підприємств; зменшення капітального будівництва, зростання безробіття у сільській місцевості [2]. 
Наведена ситуація, у тому числі, викликана недостатньою інвестиційною активністю сільгосппідприємств 3 радіаційно-забруднених територій, що потребує дослідження ії динаміки на прикладі агровиробників з РЗТ Житомирської області (табл. 1).

На фроні збільшення інвестицій у основний капітал сільськогосподарських підприємств 3 РЗТ Житомирської області у 2002-2019 роках (+79 млн. грн.), про проблеми 3 інвестиційною активністю свідчить негативний тренд 2017-2019 років відносно вкладень сільгосппідприємств області у основний капітал (-63 млн. грн.).

Акцентуємо увагу на зменшенні співвідношення інвестицій до виручки виробників сільськогосподарської продукції з РЗТ у 2017-2019 роках майже до рівня 2005 року, що підтверджує зниження інвестиційної активності. Також відмічаємо низькі значення у 2019 році показників «Динаміки інвестицій в основний капітал сільськогосподарських підприємств» та «Частки інвестицій в сільськогосподарську галузь до загального обсягу інвестицій в основний капітал», що підтверджує висновки про зниження інвестиційної активності сільськогосподарських підпри- ємств з РЗТ Житомирської області. У той же час частка освоєних інвестицій в основний капітал до загальної суми інвестицій в основний капітал була у 2019 році найвищою за період дослідження.

Наведена ситуація вимагає пошуку шляхів удосконалення інвестиційного забезпечення сільськогосподарських підприємств на територіях радіаційного забруднення 3 використанням економіко-математичного моделювання.

3 урахуванням вищевикладеного, в якості результативної ознаки ( $Y$ ) пропонуємо обрати обсяг продукції сільськогосподарських підприємств на територіях радіаційного забруднення. Факторними ознаками $є$ вартість фрінансового лізингу сільськогосподарських підприємств на територіях радіаційного забруднення $\left(x_{1}\right)$; вартість кредитів, наданих кредитними спілками на сільськогосподарську діяльність $\left(x_{2}\right)$; вартість кредитування сільськогосподарських підприємств депозитними корпораціями, крім НБУ $\left(x_{3}\right)$ (табл. 2).

Спираючись на отримані дані, рівняння лінійної багатофракторної регресії для встановлення залежності обсягу продукції сільськогосподарських підприємств на територіях

Динаміка інвестиційної активності сільськогосподарських підприємств з РЗТ

Таблиця 1 у Житомирській області, 2002-2019 роки

\begin{tabular}{|l|c|c|c|c|c|c|c|c|c|}
\hline \multicolumn{1}{|c|}{ Назва показника } & \multicolumn{7}{c|}{ Роки } & \multicolumn{2}{c|}{ Відхиленн, +l- } \\
\cline { 2 - 10 } & $\mathbf{2 0 0 2}$ & $\mathbf{2 0 0 5}$ & $\mathbf{2 0 1 0}$ & $\mathbf{2 0 1 5}$ & $\mathbf{2 0 1 7}$ & $\mathbf{2 0 1 8}$ & $\mathbf{2 0 1 9}$ & $\mathbf{2 0 1 9 / 2 0 0 2}$ & $\mathbf{2 0 1 9 / 2 0 1 5}$ \\
\hline $\begin{array}{l}\text { Інвестиції в } \\
\text { основний капітал } \\
\text { сільськогосподарських } \\
\text { підприємств, тис. грн. }\end{array}$ & 25 & 25 & 26 & 29 & 167 & 148 & 104 & 79 & 75 \\
\hline $\begin{array}{l}\text { Співвідношення } \\
\text { інвестицій до виручки } \\
\text { сільськогосподарських } \\
\text { підприємств }\end{array}$ & 0,06 & 0,08 & 0,05 & 0,11 & 0,19 & 0,15 & 0,09 & 0,03 & $-0,02$ \\
\hline $\begin{array}{l}\text { Динаміка інвестицій } \\
\text { в основний капітал } \\
\text { сільськогосподарських } \\
\text { підприємств, \% }\end{array}$ & 0 & 0,92 & 1,36 & 2,47 & 69,31 & 98,34 & 33,15 & 33,15 & 30,68 \\
\hline $\begin{array}{l}\text { Частка інвестицій } \\
\text { в сільськогосподарську } \\
\text { галузь до загального } \\
\text { обсягу інвестицій } \\
\text { в основний капітал, \% }\end{array}$ & 11,8 & 11,5 & 11,0 & 3,1 & 2,7 & 6,1 & 2,4 & $-9,4$ & $-0,7$ \\
\hline $\begin{array}{l}\text { Освоєно інвестицій в } \\
\text { основний капітал, тис. грн. }\end{array}$ & 23 & 24 & 25 & 28 & 73 & 143 & 102 & 79 & 74 \\
\hline $\begin{array}{l}\text { Частка освоєних інвести } \\
\text { цій в основний капітал до } \\
\text { загальної суми інвестицій } \\
\text { в основний капітал }\end{array}$ & 92,0 & 96,0 & 96,2 & 96,6 & 43,7 & 96,6 & 98,1 & 6,1 & 1,5 \\
\hline
\end{tabular}


Таблиця 2

Вихідні дані для моделювання інвестиційного забезпечення розвитку сільськогосподарських підприємств на територіях радіаційного забруднення

\begin{tabular}{|c|c|c|c|c|}
\hline Рік & $\begin{array}{c}\text { Продукція } \\
\text { сільськогос- } \\
\text { подарських } \\
\text { підприємств, } \\
\text { млн. грн. }(Y)\end{array}$ & $\begin{array}{c}\text { Вартість } \\
\text { оінансового } \\
\text { лізингу сільсько- } \\
\text { господарських } \\
\text { підприємств, } \\
\text { млн. грн. }\left(x_{1}\right) ;\end{array}$ & $\begin{array}{c}\text { Кредити, надані } \\
\text { кредитними } \\
\text { спілками, на сіль- } \\
\text { ськогосподарську } \\
\text { діяльність, } \\
\text { млн. грн. }\left(x_{2}\right)\end{array}$ & $\begin{array}{c}\text { Кредитування } \\
\text { сільськогосподар- } \\
\text { ських підприємств } \\
\text { депозитними кор- } \\
\text { пораціями, крім } \\
\text { НБУ, млн. грн. }\left(x_{3}\right)\end{array}$ \\
\hline 2013 & 179605,8 & 811,4 & 40,8 & 8192 \\
\hline 2014 & 184095,8 & 951,1 & 67,4 & 11874 \\
\hline 2015 & 172129,7 & 1517,54 & 191,3 & 16508 \\
\hline 2016 & 201564,0 & 2712,59 & 209,9 & 28812 \\
\hline 2017 & 197935,9 & 3153,8 & 72,5 & 26026 \\
\hline 2018 & 194886,5 & 3966,2 & 80,0 & 34143 \\
\hline 2019 & 233696,3 & 17232,6 & 139,1 & \\
\hline
\end{tabular}

Джерело: розроблено на основі досліджень [6; 7]

радіаційного забруднення від джерел фрінансування матиме такий вигляд:

$$
Y=a_{0}+a_{1} x_{1}+a_{2} x_{2}+a_{3} x_{3},
$$

Встановлена тіснота зв'язку дозволила поглибити дослідження та обрати в якості результативної ознаки (Y) обсяг валової продукції сільського господарства РЗТ, фракторних ознак - вартість фрінансового лізингу $\left(x_{1}\right)$, вартість кредитів, наданих кредитними спілками $\left(x_{2}\right)$, вартість кредитування депозитними корпораціями, крім НБУ $\left(x_{3}\right)$. В результаті математичних розрахунків отримано рівняння:

$$
Y=16925,86+2,0 x_{1}-4,81 x_{2}+1,24 x_{3}
$$

При цьому, коефріцієнті детермінації становить $\mathrm{R}^{2}=0,93$. Це забезпечує максимальну наближеність $\hat{Y}$ до фрактичних значень $Y$.

Стандартні помилки оцінок параметрів моделі інвестиційного забезпечення розвитку сільськогосподарських підприємств на територіях радіаційного забруднення є такими:

$$
\begin{aligned}
& \delta_{\mathrm{a} 0}=18864,57 ; \\
& \delta_{\mathrm{a} 1}=1,69 ; \\
& \delta_{\mathrm{a} 2}=116,75 ; \\
& \delta_{\mathrm{a} 3}=1,12 .
\end{aligned}
$$

Фактичне значення $F$-критерію дорівнює 13,003; а табличне - при ступенях свободи $\mathrm{V}_{1}=\mathrm{m}=3$ і $\mathrm{V}_{2}=n-\mathrm{m}-1=3$ та рівні значущості $\alpha=0,05$ дорівнює $F_{\text {табл }}=9,28$. Оскільки $F>F_{\text {табл }}$, то доцільно вважати, що розроблена економікоматематична модель інвестиційного забезпечення розвитку сільськогосподарських підприємств на територіях радіаційного забруднення $€$ достовірною та підтверджується гіпотеза, що кількісна оцінка зв'язку між залежною і незалежними змінними моделі $є$ істотною.
Значимість коефріцієнтів регресії перевіряється за допомогою $t$-критерію: $\mathrm{t}_{0}=19,54$; $\mathrm{t}_{1}=2,67 ; \mathrm{t}_{2}=1,90 ; \mathrm{t}_{3}=1,98$. Табличне значення $t$-критерію при рівні значущості $\alpha=0,05$ та $\mathrm{V}=\mathrm{n}-\mathrm{m}-1=3$ ступенів вільності становить $\mathrm{t}_{\text {табл }}=1,638$. Зважаючи на те, що фрактичні значення t-критерію $€$ більшими за табличні, то коефріцієнти оцінки параметрів $\mathrm{a}_{1}, \mathrm{a}_{2}, \mathrm{a}_{3}$ характеризують істотний зв'язок між фракторними ознаками та результативною. Тобто всі параметри моделі інвестиційного забезпечення розвитку сільськогосподарських підприємств на територіях радіаційного забруднення $€$ статистично значимими 3 ймовірністю 0,8.

3 врахуванням вищевикладеного, в табл. 3 представлені коефріцієнти оцінки впливу фракторних ознак на результативність при моделюванні інвестиційного забезпечення розвитку сільськогосподарських підприємств на територіях радіаційного забруднення.

Як видно з табл. 3, при збільшенні на 1\% вартості фрінансового лізингу або обсягу кредитування депозитними корпораціями, крім НБУ, сільськогосподарських підприємств на територіях радіаційного забруднення, обсяг продукції збільшиться на 5\% та 11\% відповідно. В свою чергу, збільшення обсягу кредитних ресурсів, наданих кредитними спілками, на ведення сільськогосподарської діяльності на територіях радіаційного забруднення має негативний вплив на обсяг продукції. Так збільшенням обсягу кредитів кредитних спілок на ведення сільськогосподарської діяльності на територіях радіаційного забруднення на $1 \%$ призведе до зменшення обсягу продукції на 3\%.

Таким чином, моделювання інвестиційного забезпечення сільськогосподарських підпри- 
Коефіцієнти оцінки впливу факторних ознак на результативність при моделюванні інвестиційного забезпечення розвитку сільськогосподарських підприємств на територіях радіаційного забруднення

\begin{tabular}{|c|c|c|c|}
\hline Показник & $\begin{array}{c}\text { Вартість фрінансового } \\
\text { лізингу сільськогоспо- } \\
\text { дарських підприємств, } \\
\text { млн. грн. }\left(x_{1}\right) ;\end{array}$ & $\begin{array}{c}\text { Кредити, надані } \\
\text { крединими сппілками, } \\
\text { сільськогосподар- } \\
\text { ську діяльність, } \\
\text { млн. грн. }\left(x_{2}\right)\end{array}$ & $\begin{array}{c}\text { Кредитування сіль- } \\
\text { ськогосподарських } \\
\text { підприємств депозит- } \\
\text { ними корпораціями, } \\
\text { крім НБУ, млн. грн. }\left(x_{3}\right)\end{array}$ \\
\hline Е-коефріцієнт & 0,05 & $-0,03$ & 0,11 \\
\hline$\beta-$ коесріцієнт & 0,60 & $-0,16$ & 0,49 \\
\hline$\Delta-$ коесріцієнт & 0,59 & $-0,03$ & 0,44 \\
\hline
\end{tabular}

Джерело: власні дослідження

ємств на територіях радіаційного забруднення дозволило виявити $з$ однієї сторони ключову необхідність оновлення основних засобів, що $є$ базисом для успішної фрінансово-господарської діяльності агровиробників з РЗТ, а 3 іншої, в якості найбільш ефективного інвестиційного інструменту для таких сільгосппідприємств фрінансовий лізинг.

Відзначаємо необхідність комплексного підходу щодо використання фрінансового лізингу у інвестиційному забезпеченні сільськогосподарських підприємств на територіях радіаційного забруднення, що сприятиме: прискоренню їх матеріально-технічного переозброєння; розширенню доступу малих підприємств до фрінансових ресурсів; створенню мережі сільськогосподарських обслуговуючих кооперативів.

Висновки. Підсумовуючи проведене дослідження, можемо визначити проблеми 3 інвестиційним забезпеченням виробників сільськогосподарської продукції з радіаційнозабруднених територій. Для вирішення проблеми було запропоновано використовувати економіко-математичне моделювання, що, у свою чергу, дозволило виявити ключове джерело залучення фрінансування для сільськогосподарських підприємств з РЗТ (фрінансовий лізинг). Окремо було наголошено на необхідності комплексного підходу до використання фрінансового лізингу к контексті удосконалення інвестиційного забезпечення сільськогосподарських підприємств на територіях радіаційного забруднення в Україні.

Подальші дослідження необхідно сконцентрувати на удосконаленні державного регулювання інвестиційного забезпечення сільськогосподарських підприємств на територіях радіаційного забруднення, а також на розробці пропозицій по застосуванню системи інвестиційного забезпечення сільгоспвиробників з РЗТ в країні.

\section{СПИСОК ВИКОРИСТАНИХ ДЖЕРЕЛ:}

1. Супрун О.О. Розвиток інвестиційного забезпечення діяльності сільськогосподарських підприємств. Вісник соціально-економічних досліджень, 2014, 2, 156-163. URL: http://nbuv.gov.ua/UJRN/Vsed_2014_2_27

2. Бусленко Б.В. Потреба в залученні інвестицій в агропромисловий комплекс України. 2015. URL: http://nauka.kushnir.mk.ua/?p=71179

3. Kisil M.I. Strategic investment directions for the development agriculture of Ukraine. Економіка АПК, 2015, 8, 39-44. URL: http://www.eapk.org.ua/en/contents/2015/08/39

4. Малиновський А.С., Павловська Л.Д. Емпіричні оцінки проблем розвитку радіаційно забруднених сільських територій в Україні. Роль соціального капіталу та локальних ініціатив у забезпеченні сільського розвитку : Доп. Міжнар. симп. Житомир : ДВН3 «Держ. агроеколог. ун-т.», 2007. С. 138-145.

5. Калиненко Л.В., Перепелятников Г.П., Іванова Т.М. та ін. Рекомендації щодо використання сільськогосподарських угідь населених пунктів, які за радіологічними показниками можуть бути виведені за межі // зон. Київ, 2008. 108 с.

6. Державна служба статистики України. Головне управління статистики у Житомирській області. Статистична інфрормація. 2020. URL: http://www.zt.ukrstat.gov.ua

7. Державна служба статистики України. Статистична інформація. 2020. URL: http://www.ukrstat.gov.ua 


\section{REFERENCES:}

1. Suprun, O.O. (2014). Rozvytok investytsiinoho zabezpechennia diialnosti silskohospodarskykh pidpryiemstv [Investment support development of agricultural enterprises]. The Journal of social and economic studies, 2, 156-163. Retrieved from: http://nbuv.gov.ua/UJRN/Vsed_2014_2_27 (in Ukrainian)

2. Buslenko, B.V. (2015). Potreba v zaluchenni investytsii v ahropromyslovyi kompleks Ukrainy [The necessity to attract investments in agricultural sector of Ukraine]. Retrieved from: http://nauka.kushnir.mk.ua/?p=71179 (in Ukrainian)

3. Kisil, M.I. (2015). Strategic investment directions for the development agriculture of Ukraine. Economics of AIC, no. 8, 39-44. Retrieved from: http://www.eapk.org.ua/en/contents/2015/08/39 (in Ukrainian)

4. Malynovskyi, A.S., Pavlovska, L.D. (2007). Empirychni otsinky problem rozvytku radiatsiino zabrudnenykh silskykh terytorii v Ukraini [The empiric assessments of the problem of radioactively contaminated rural areas development in Ukraine]. The role of social capital and local initiatives in supporting agricultural development: Thesis of International symp. Zhytomyr: SHEE "State Agroecol. Univ.", 138-145. (in Ukrainian)

5. Kalynenko, L.V., Perepeliatnykov, H.P., Ivanova, T.M. ta in. (2008). Rekomendatsii shchodo vykorystannia silskohospodarskykh uhid naselenykh punktiv, yaki za radiolohichnymy pokaznykamy mozhut buty vyvedeni za mezhi II zon [Recommendations on the implementation of agricultural areas of localities, which based on radioactive indexes can be brought out of II zones]. Kyiv, 108. (in Ukrainian)

6. Derzhavna sluzhba statystyky Ukrainy. Holovne upravlinnia statystyky u Zhytomyrskii oblasti (2020). Statystychna informatsiia [Statistical information]. Retrieved from: http://www.zt.ukrstat.gov.ua (in Ukrainian)

7. Derzhavna sluzhba statystyky Ukrainy (2020). Statystychna informatsiia [Statistical information]. Retrieved from: http://www.ukrstat.gov.ua (in Ukrainian) 